\title{
The Determinant Factors of Technology Adoption for Improving Firm's Performance: An Empirical Research of Indonesia's Electricity Company
}

\author{
Zainal Arifin, ${ }^{1}$ Firmanzah, ${ }^{2}$ Avanti Fontana, ${ }^{2}$ and Setyo Hari Wijanto ${ }^{2}$ \\ 1) PT PLN, Indonesia; ${ }^{2}$ Faculty of Economics and Business, Universitas Indonesia
}

\begin{abstract}
This study investigates the determinant factors of technology adoption by connecting Technology Organizational Environment (TOE) with the dynamic capability factors. Using 518 respondents representing 222 business units of Indonesia's electricity company, the study found that only the absorptive capability has a positively significant effect on technology adoption. Practically, the study emphasizes that without the absorptive capability for managing the resource, the core competence of a firm will not occur and the adoption of technology will be less effective. Another finding is the absorptive capability's typology mapping the eight technology adoption statuses in an organization, based on three of the determinant factors: the externalities, entrepreneurial leadership and slack resources.
\end{abstract}

\begin{abstract}
Abstrak: Penelitian ini menguji berbagai faktor penentu pengadopsian teknologi dengan mengbubungkan lingkungan organisasional teknologi dengan faktor kapabilitas dinamis. Dengan menggunakan 518 responden yang mewakili 222 unit bisnis Perusabaan Listrik. Negara (PLN), studi ini menemukan bahwa hanya kapabilitas absorptif yang mempunyai pengarub positif signifikan pada pengadopsian teknologi. Dalam praktiknya, studi ini menekankan bahwa tanpa kapabilitas absorptif untuk. pengelolaan sumber daya, kompetensi inti perusabaan tidak akan tercipta, sebingga pengadopsian teknologi menjadi kurang efektif. Temuan lain adalah tipologi kapabilitas absorptif memetakan 8 (delapan) status pengadopsian teknologi dalam organisasi berdasarkan tiga faktorpenentunya: eksternalitas, kepemimpinan keewirausahaan dan sumber daya yang tertunda.
\end{abstract}

Keywords: absorptive capability; electricity utility; technology adoption; TOE framework

JEL classification: D83, L94, O33

* Corresponding author's e-mail: zainal.arifin22@pln.co.id 


\section{Introduction}

Technology has improved and continues to improve the way we live, communicate, interact socially and do business. In the context of a firm, Dussauge (1992) argued that technology is a factor affecting many aspects of a firm's strategy. The technological changes and innovations were fundamental sources of productivity and sustainable growth (Morrris 1998; Johnson et al. 2008; Van Ark et al. 2008). Thus, viewing technology's adoption as a consistent process is the key to successfully adopt and use technology. Strategically, the successful adoption of technology by firms significantly affects their competitive advantage, especially their performance (Porter 1985; Barney 1991; Majundar and Ventaraman 1998; Rayport and Jaworski 2004; Kotler and Keller 2006).

Concerning this issue, some research studying the use of technology in production processes to increase a firm's productivity has been conducted in the 19th and 20th centuries (Abramovitz 1956; Solow 1957; Saloner and Shepard 1995). Further studies have linked technology to firms' performance, as measured through wages, the firms' productivity, growth, and other factors (Bressler et al. 2011). Many studies argued that technology's adoption had significantly affected the firms' performance (SSinha and Noble 2008; Sabbaghi and Vaidyanathan 2008; Benitez-Amado et al. 2010; Bressler et al. 2011; Adewoje and Akanbi 2012).

However the impact of technology's adoption remains inconclusive. Some studies proved that IT's (Information Technology) adoption contributed to an up to 81 percent increase in output (Brynjolfsson and Hitt 2000), reduced labor costs by up to 40 percent (Rodd 2004), increased efficiency and the total productivity of the adopting firms
(Chandrasekhar et al. 2008; Benitez-Amado et al. 2010), enhanced the firms' profitability (Adewoje and Akanbi 2012; Kabiru and Usman 2012), and improved the firms' financial profits (Sarker and Valacich 2010). On the other hand some empirical studies did not find any relevant improvements in productivity associated with investment in technology (Quinn and Baily 1994; Becchetti et al. 2006). Berndt and Morrison (1995) also found a negative relationship between profitability and investment in IT. Thus, the notion of the productivity paradox of IT was created and has been one of the main issues in IT research areas (Raymond and Blili 1997). Shu and Strassmann (2005) also noticed that ICT technology cannot improve firms' earnings in terms of their return on assets. In addition a quantitative research by Jawabreh et al. (2012) found that there was a negative correlation between the adoption of technology and the profit rate of the airlines adopting it.

This paradox requires further research to examine what are the initial determinant factors of technology's adoption and what is the mediating factor which determines the relationship between technology's adoption and firm's performance. At the firms' level, the TOE (Technology - Organization - Environment) model has been considered to be the most effective tool explaining technology's adoption (Oliveira and Martins 2011). However it is not sufficient to analyze technology's adoption in relation to a firm's performance in dynamic circumstances. Viewing technology's adoption as a process for managing some resources; it could be analyzed and determined by RBV (Resource Based View). In order to develop its competitive advantage, a firm must have resources and capabilities that are superior to its competitors (Barney 1991). The firm's resources and capabilities together form its distinctive competencies. 


\section{Literature Review}

The study of the adoption of technology can be approached from several levels (Taylor and Tod 1995). Some researchers investigate its adoption from a macro-view within the social context or at the country level (Kiiski and Pohjola 2002). Others have examined this issue at the organizational or intra-firm level (Plouffe et al. 2001). Some others focused on investigating technology's adoption by its individual determinants (Bagozzi et al. 1992; Davis 1989; Venkatesh et al. 2003).

Extending Taylor and Todd's (1995) classification, the research into the determinants of technology's adoption could be distinguished into three streams: Firstly, those based on intention-based models relying on how users accept or do not accept it, and further use or reject technology; secondly, diffusion innovation, focusing on why and how a new technology spreads around an organization or community; and thirdly, how the new technology affects the goals, objectives and performance of an organization. The first stream was exemplified by such theories as the Technology Acceptance Model or TAM (Davis 1989) and the Unified Theory of Acceptance and Use of Technology (UTAUT) (Venkatesh et al. 2003). The second stream was primarily represented by the Diffusion Of Innovation or DOI theory (Rogers 1963; 1983; 1995), and the Technology Adoption Life Cycle or TALC model (Rogers et al. 1957; Moore 1991). The last one was dominantly explained by organizational theories such as the Technology Organization and Environment or 'TOE' framework (Tornatzky and Fleischer 1990). Considering the content and context of the research (de Wit and Meyer 2010), and exploring all those main related theories, this paper proposed the TOE frame- work as the most relevant theory for searching for the determinant factors of technology's adoption at the firms' level. The three elements present both constraints and opportunities for technological innovation (Oliveira and Martins 2011).

Although RBV could explain technology's adoption processes for achieving a firm's competitive advantage, it is essentially a static theory since it does not explain how the firm's resources and capabilities evolve over time to be the basis of its competitive advantage (Priem and Butler 2001). RBV research does not essentially examine the effects of a firm's external environment on how it manages its resources. Hence there was a need for a theory which would not just view a firm as a bundle of resources, but also the mechanisms by which firms' learn and accumulate new skills and capabilities, and the forces that limit the ratio and direction of this process (Teece et al. 1990). Then the concept of 'dynamic capability' emerged; it reflects how quickly the capabilities and resources of the company change following changes in an increasingly dynamic environment (Eisenhardt and Martin 2000).

Referring to the previous Dynamic Capabilities (DC) research, the most important relationship in this field is that of dynamic capabilities with performance. The literature is divided (Silva 2007); some explain that there is a direct relationship between firms' dynamic capabilities and their performance or competitive advantage (Makadok 2001; Zollo and Winter 2002). Others have linked dynamic capabilities to competitive advantage but have asserted that this link is indirect (Zott 2003; Helfat and Peteraf 2003; Ambrosini and Bowman 2009; Wang and Ahmed 2007). Contrary to those ideas, Helfat and Peterraf (2003) argued that dynamic capabilities did not necessarily lead to 
a competitive advantage. However to sustain their competitive advantage, firms need to renew their stock of valuable resources, as their external environment changes because of their dynamic capabilities' processes (Teece et al. 1997; Makadok 2001; Helfat and Peterraf 2003; Wang and Ahmed 2007; Majumdar et al. 2010).

Nowadays a firm's absorptive capacity is mostly conceptualized as a dynamic capability (Abreu et al. 2008). Following key empirical studies pertinent to DCs from 1996 to 2012, Dynamic capability in the form of absorptive capability has been implemented at many levels and in the context of numerous studies at this time. It has been widely examined at the firms' level (Teece et al. 1997), industries' level (Lin and Lin 2008), intrafirm (Amlakuet al. 2012), inter-firm (Brady and Davis 2004), SMEs (Griffith and Har vey 2001) and non-profit organizations (Zahra and George 2002.

In addition absorptive capability is the most applicable form of DC for many fields/ subjects. The implementation of absorptive capability has been included in studies focusing on research and development (Caloghirou et al. (2004), knowledge management (Corso et al. 2006), organizational structures (Lin 2012), human resources (Caloghirou et al. 2004; Freels 2005), external interactions (Caloghirou et al. 2004), social capital (Landry et al. 2002), supplier integration (Malhotra et al. 2005), client integration (Johnsen and Ford 2006) and inter-organizational fit (Lane and Lubatkin 1998).

These existing various relationships of absorptive capability to firms' performance requires further research to examine what are the determinant factors of absorptive capability's effects and what is the mediating factor that connects the relationship between absorptive capability to firms' performance.

\section{Hypotheses}

Following the TOE framework, there were some relevant environmental factors influencing firms' adoption of technology, such as the role of partners (Al-Qirim 2006; Jeyaraj et al. 2006; Scupola 2009), competitive pressure (Porter and Millar 1985), and regulatory compliance (Lai 2008, and Lin 2013). As well as their effect on the adoption of technology, those external factors also influence how leaders' perceive the way to manage their organizations more efficiently and effectively. External effects are mostly related to the character and behavior of the management, and how the organization interacts with its environmental dynamics; its organizational leadership.

When the industrial environment was more competitive, turbulent and unpredictable, it brought severe pressure to bear on the types of analytical approaches to management. The cornerstone of competition pushed people to think that analytical planning, which leads to competitive success, was no longer feasible (Gupta et al. 2004). In this chaotic and dynamic environment, where the power of analytical leadership was diminished, the need the entrepreneurial leadership by organizations was higher (McGrath 1997). However the need for and emergence of entrepreneurial leadership was caused by the recent dynamic circumstance, so entrepreneurial leadership clearly was affected by external factors (McGrath and MacMillan 2000). Additionally by considering the context of our study, we prefer to use 'externalities' for representing all the determinant factors of technology's adoption by an external organization; the external networks, regulations and social issues etc.

Entrepreneurial leadership is known as the dynamic process of presenting a vision, 
building commitment among followers, and risk acceptance when facing opportunities, which causes the efficient use of the available resources, along with discovering and utilizing new resources, with respect to the leader's vision (Lee and Venkataraman 2006). The most important feature of entrepreneurial leadership is creating value, by discovering new opportunities and creating new strategies in order to gain a competitive advantage (Schulz and Hofer 1999). Moreover, entrepreneurial leadership's development occurs during the process of transforming the knowledge acquired from experience and social interaction, allowing the opportunities for personal development and business creation to be identified (Churchill et al. 2013). Hence:

Hypothesis 1: the externalities positively affect the entrepreneurial leadership.

On one hand, such a capability mostly depends on technological collaborations, formal or informal networks between firms and their external pressures, such as industries and professional groups, and between industry and university laboratories (Massini and Lewin 2003). Furthermore, this relationship would increase the effectiveness of knowledge's absorption capability as it enhances the complementary asset of experience inside the firm (Cohen and Levinthal 1990). Then, collaboration and partnerships could be a learning resource for an organization, that helps companies to recognize dysfunctional routines and to avoid hidden strategic constraints (Teece 2007). While the study by Helfat and Peterraf (2003) stated that all dynamic capability processes adapt, integrate and reconfigure internal and external organizational skills, resources and functional competences, in order to match the requirements of a changing environment. It was further emphasized by Rindova and Kotha
(2001) who explained how a dynamic market and turbulent industry pushes firms to enter tough fields of competition through their continuous organizational absorptive capabilities. So:

Hypothesis 2: the externalities positively affect absorptive capability.

As well as its effect on absorptive capability, the externalities also had the effect of slackening the resources. Bourgeois (1981) argued that, in practical terms, slack resources can serve some primary functions. They allow the organization to offer salaries that are higher than those actually required to retain the employees' services. In addition slack resources also aid conflict resolution when problem solving. Other functions of slack resources are as a buffering mechanism, used to adapt to sudden changes in the environment. Then the most important function of slack resources is to facilitate strategic or creative behavior to help make long-term decisions such as seizing a business opportunity, developing a new product, or realizing a growth strategy. In summary, the functions of slack resources are related to internal tensions within the organization, and also to external tensions between the organization and its environment (the externalities). Then some studies found that environmental conditions or externalities are one of the antecedents leading to the development of slack resources (Stevens 2002; Donada and Dostaler 2005). Thus:

\section{Hypothesis 3: the externalities positively affect slack resources.}

Some recent literature has shown that firms benefit from having absorptive capabilities when crafting new business and corporate strategies (Ambrosini and Bowman 2009); learning new skills (Zollo and Winter 2002; Ambrosini and Bowman 2009); lever- 
aging their other resources (Ambrosini and Bowman 2009); introducing innovative programs that stimulate strategic changes (Repenning and Sterman 2002); and successfully commercializing new technologies generated through their R\&D activities (Marsh and Stock 2003). Other studies argue that absorptive capability's effects are indirect; they emerge through such things as entrepreneurial capability (Zahra 2006) and organizational leadership (Hejazi et al. 2012).

Even though there are opposite views in some researches' findings about the importance of entrepreneurial and leadership activities for the conception, development, configuration and maintenance of the absorptive capabilities in an organization (Repenning and Sterman 2002; Zahra et al. 2006), some recent studies argue that several best practice processes supporting knowledge acquisition, knowledge creation, and knowledge integration in firms have affected their entrepreneurial leadership's status (Simsek et al. 2010). So:

\section{Hypothesis 4: the absorptive capability positively affects entrepreneurial leadership.}

Internally slack resources could be a valuable resource to improve firms' performance through managerial initiatives. Indeed, managerial capability is necessary to find ways to devote slack resources to productive activities (Burkart et al. 2003). A positive relationship between slack resources and firms' performance is more likely in firms with higher levels of managerial dynamic capability (McKelvie and Davidsson 2009). They found that four dynamic capabilities had positive effects stemming from their access to particular resources, and provided empirical support for the notion of treating the firm as a dynamic flow of resources, as opposed to a static stock. Along with the study, recent empirical scholarship suggests that in both the dynamic managerial capabilities (Ireland et al. 2003) and the micro-level foundations of routines and capabilities (Felin and Foss 2005), researchers have found that firms' absorptive capabilities have fundamental roles in the firms' slack resources' status (McKelvie and Davidsson 2009). Hence:

\section{Hypothesis 5: the absorptive capability positively affects slack resources.}

Due to investigating technology's adoption using RBV logic, which leads to static circumstance, firms need dynamic capabilities to renew their stocks of valuable resources, as their external environment changes (Teece et al. 1997; Makadok 2001; Wang and Ahmed 2007; Majumdar et al. 2010). Considering that a firm's absorptive capacity is mostly conceptualized as a dynamic capability, which has been widely researched at the level of firms, sectors, regions and nations, based on a wide consensus (Abreu et al. 2008). It is the ability of the organization to recognize the values of novelty in its external forms, then assimilate and apply it for commercial purposes (Cohen and Levinthal 1990). Specifically, the absorptive capability measures a firm's ability to absorb, assimilate, and exploit an innovation throughout the firm (Link et al. 2002). The higher the level of its absorptive capability a firm demonstrates, the more it exhibits its dynamic capabilities (Zaheer and Bell 2005).

Regardless that there are different views of dynamic capabilities' effects on firms' advantages, recently there have emerged studies arguing that the absorptive capability builds and reconfigures resource positions (Eisenhardt and Martin 2000), zero-order capabilities (Winter 2003), operational routines (Zollo and Winter 2002) or operational capabilities (Helfat and Peteraf 2003) and, 
through them, affects performance. This chain of causality is designated as an indirect link between absorptive capabilities and performance. The indirect relationship results from the idea that absorptive capabilities originated and defined firms' individual resource configurations, including their functional capability processes, which shape the firms' competitiveness and therefore performance (Zott 2003). Therefore this paper argues that technology's adoption is one of the functional capabilities which mediate the relationship between the absorptive capabilities and the firm's performance. Thus:

\section{Hypothesis 6: the absorptive capability positively affects technology's adoption.}

Based on strategic management practices, another significant organizational factor of technology's adoption is organization leadership. Fundamentally, leadership has an influence over organizations via their strategic decision-making, determining organizational structures and managing the organizational process (Day and Lord 1988; Nahavandi 1993). Moreover a leader with good perceptional resources will contribute to higher performance (Dessler 1994). Additionally Devarajan et al. (2003) found that the success of firms in dynamic industries depended on 'thriving innovation activity', that in turn is primarily driven by 'effective entrepreneurial leadership'. Such leadership, as represented by top management, plays a very critical role in driving innovation in firms, and in mastering its dynamics (Kuczmarski 1998; Kipp and Michael 2001). It could be summarized that the key factor determining successful technological adoptions under these circumstances is the 'effective entrepreneurial leadership' of the organization (Devarajan et al. 2003). So:
Hypothesis 7: the entrepreneurial leadership positively affects technology's adoption.

TOE's technological and organizational context describes that technology's adoption depends on the pool of resources exceeding the minimum necessary to produce a given level of organizational output, or slack resources (Lin 2013). The raw materials' input to technology's adoption process also includes tangible and intangible assets (Prakash et al. 2008). Instead of technology, some TOE focused studies postulated that slack sources for technology's adoption were financial (Franquesa and Brandyberry 2009), knowledge (Jeyaraj et al. 2006; Sabherwal et al. 2006; Lin 2013; Wang et al. 2013), and employee or human capital (Wang et al. 2013; Vanacker et al. 2013). In conclusion, such resources have a positive effect on a firm's flexibility and innovation in a dynamic environment, (Damanpour 1996; Judge et al. 2001) and provide organizations with the ability to be proactive as well as defensive in adopting new technologies or designing new lines of services (Lawson 2001; and Daniels et al. 2004). Thus:

\section{Hypothesis 8: slack resources positively affect the adoption of technology.}

Although there are still debatable results about the effect of technology's adoption on firms' performance; most literature shows that the use of new technology during production increases a firm's productivity (Abramovitz 1956; Solow 1957; Saloner and Shepard 1995). Many recent researchers argue that technology's adoption brings down the operational costs (Saloner and Shepard 1995; Rodd 2004; Chandrasekhar et al. 2008; Benitez-Amado et al. 2010), contributes to output increases, even if they are only marginal, (Brynjolfsson and Hitt 2000; and 
Adewoje et al. 2012), improves efficiency and effectiveness (Milne 2006; Sabbaghi and Vaidyanathan 2008; Rusli 2012), reduces environmental impacts by lowering energy costs (Bressler et al.; 2011), and also leads to significant reductions in firms' mortality rates (Sinha and Noble 2008). Matching those studies, we argue that technology's adoption has significant effects on a firm's performance. Hence:

Hypothesis 9: the adoption of technology positively affects the firm's performance

\section{The Proposed Model}

All nine hypotheses construct a hypothetical conceptual model as the following figure (Figure 1) shows, explaining the relationship between the determinant factors of technology's adoption at the firms' level. The model's logic starts from externalities as the antecedents; the organization is driven by the external factors. It has an effect on the three organizational factors: Entrepreneurial leadership, absorptive capability, and slack resources. So absorptive capability is the determining factor for entrepreneurial leader- ship, slack resources and technology's adoption. While both entrepreneurial leadership and slack resources directly affect technology's adoption, eventually technology's adoption will affect firms' performance. However the model should be tested empirically through a quantitative approach.

\section{Methods}

\section{Research Objective}

Starting from the TOE's view, this study analyzes the influence of externalities and absorptive capability on technology's adoption for improving firms' performance. Other determinant factors -entrepreneurial leadership and slack resources- were also investigated to assess the relationship between TOE's factors with the absorptive capability at the firms' level. The study purposes to empirically test a conceptual model of the indirect effects of the externalities and absorptive capability on the adoption of technology, which can be the key predictors of firms' performance in a dynamic environment.

\section{Figure 1. The Conceptual Hypotheses Model}

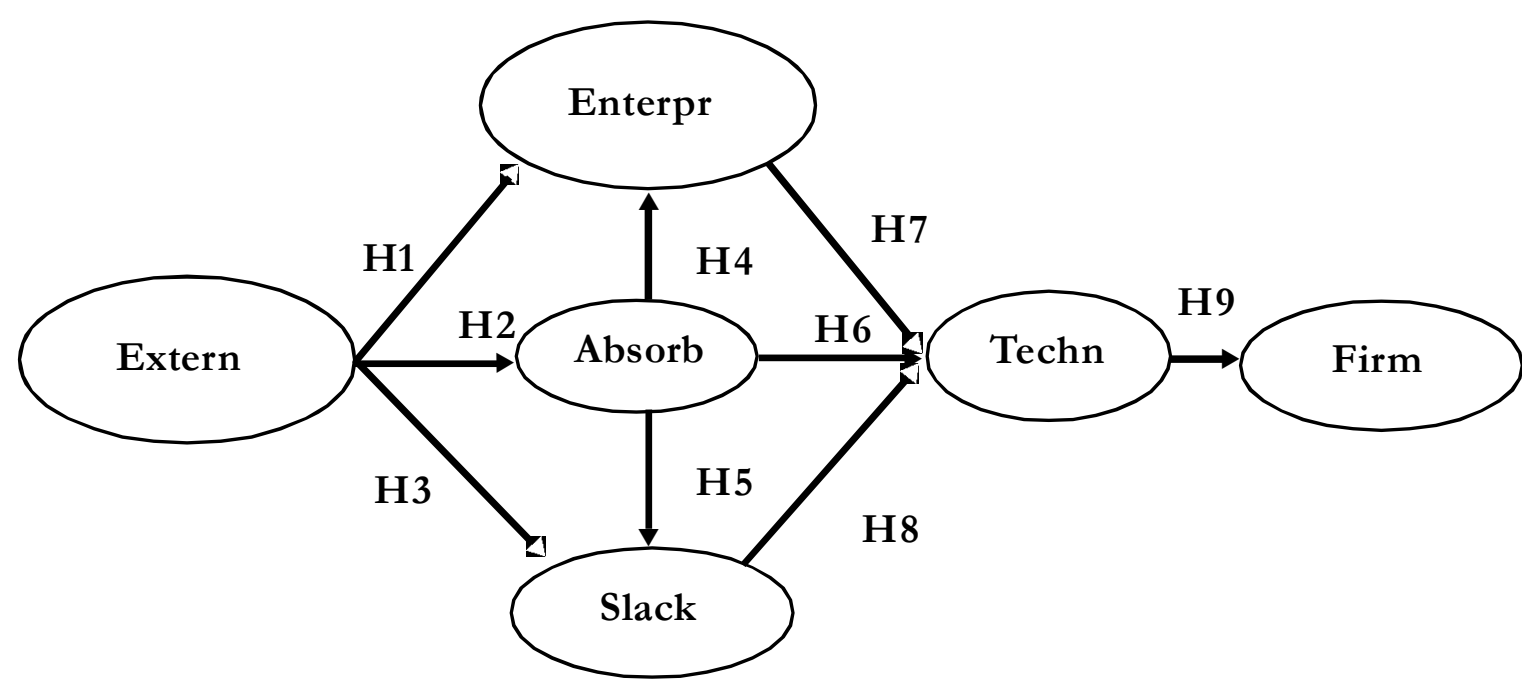




\section{Respondents and Procedure}

Using an online survey, this study was conducted by collecting data from 518 managers representing 229 business units around Indonesia belonging to the Indonesian Electricity Company (PLN). There were 222 units $(96.94 \%)$ that completed the survey correctly, 1 unit's reply $(0.4 \%)$ was considered not to be valid, and 6 units $(2.6 \%)$ did not respond at all. PLN was chosen because it represents the content and context of the research issues, namely: (1) A 'RBV perspective' company (2) a 'technology-intensive' organization where 87 percent of its assets are technological things (3) a 'comprehensive' technology adoption flow, which covers both 'top-down' and 'bottom-up' processes (4) it is a 'national company' with 40,000 employees spread out over all areas of the country.

The respondents' core business unit is for the organization of the electricity utility company's supply chain, for the generation, transmission and distribution or retail/service of electricity. Considering their similarity characteristics, the working experience of the respondents is varied, from less than 5 years, while others have 5-10 years experience and over. Meanwhile their ages are divided into three groups: Less than 30 years old, between 30-40 years old and over 40 years old. The number of samples, which exceeds 100 questionnaires, is an appropriate number for research that analyzes its data using a SEM (Structural Equation Model), especially for the overall fit measures side, which is represented by the likelihood-ratio chi-square statistic (Hair et al. 1998). The SEM analysis, which uses LISREL version 8.7 software, is done with a 'two-stage approach,' (Wijanto 2008), with the process as follows: (1) Analysis of the measurement model using Confirmatory Factor Analysis (CFA). (2) Analysis of the structural model to analyze the relationship among all the latent variables that have been simplified. (3) Analysis of the significance test results for each hypothesis to determine whether the hypothesis will be accepted or rejected.

\section{Measurement}

For measuring the externalities, 9 selected items are used, with reference to a previous study with 3 controlling variables: An external network ( Lin and Lin 2008), regulation (Lai 2008), and social issues (Asres et al. 2012). Meanwhile entrepreneurial leadership is measured by the construct of the entrepreneurial leadership data from the GLOBE (Global Leadership and Organizational Behavior Effectiveness) program (Gupta et al. 2004). It consists of 2 main dimensions: Cast enactment and transformational enactment with a total of 19 items. Then DC is represented by 'absorptive capability', which is summarized from previous DC literatures (Abreu et al. 2008). It has 4 dimensions: Knowledge acquisition, assimilation, transformation and exploitation, with 12 items. Slack resources are represented by 3 variables: technology, knowledge, and human resources (Wang et al. 2013) with 10 items. Regarding the context of this study, slack finance is neglected. Technology's adoption, which has 6 items, is measured through 2 dimensions: appropriateness and effectiveness (Mirvis et al. 1991; Hall and Kahn 2002). Then the firm's performance is observed by financial and non-financial variables with 6 items (Kabiru and Usman 2012). Overall, 62 items using 6 Likert-type scales are used to measure the 6 latent variables. 


\section{Result}

The loading factors for all the items can be seen in Appendix 1, and the result of the descriptive statistical analysis can be seen in Table 1. Even though the standard deviation is included in the analysis, the latent variables' score is still higher than average. For example, slack resources, with a standard deviation of 0.53 , has a lowest limit of $2.66(3.19-0.53)$. This value shows that most of the respondents believe that their actual perceptions are similar. Additionally based on the ANOVA test result, in general there are no differences for all the latent variables in the respondent's profile group which refer to those discriminate factors: Type, location and the size of the organization's respondents.

Then a Confirmatory Factor Analysis (CFA) is used to test how well the measured variables represent the number of constructs. It is conducted to specify the number of factors required in the data, and which measured variable is related to which latent variable. To have a good overall fit of the measurement model, some of the GOFI (Goodness of Fit Index) indicators should be higher than the standard values (NFI, NNFI, CFI, IFI, RFI, GFI and AGFI) and two others should be lower than their standard (RSMEA and Std RMR). Using LISREL the test presents the calculated value of RSMEA $=0.044$, NFI $=$ $0.97, \mathrm{NNFI}=0.98, \mathrm{CFI}=0.99, \mathrm{IFI}=0.99$, RFI $=0.96$, Std RMR $=0.045$, GFI $=0.91$ and AGFI $=0.87$. Table 2 shows that there is only one GOFI indicator that shows a marginal fit (AGFI), therefore it can be concluded that the overall fit of the structural model is good.

In addition CFA also measures the validity for all the indicators (observed variables) and the reliability of the measurement for each latent variable (construct). As presented in Table 3, from the 19 observed variables of the model, there are 2 indicators of the externalities construct (regulation and social issues) which have a SLF (Standardized Loading Factor) of $\leq 0.70$ (not good validity). The table also shows that 2 of the 6 latent variables have a CR (Construct Reliability) score of $\leq 0.70$ and a VE (Variance Extracted) score of $\leq 0.50$. This means that the latent variables of the externalities and slack resources are less reliable. However the CFA test confirmed that the overall variables of the measurement model have good reliability and validity.

Table 1. Descriptive Statistics Analysis Result

\begin{tabular}{lccccc}
\hline \multicolumn{1}{c}{ Construct } & $\begin{array}{c}\text { Number } \\
\text { of items }\end{array}$ & Mean & $\begin{array}{c}\text { Standard } \\
\text { Deviation }\end{array}$ & Skewness & Kurtosis \\
\hline Externalities & 9 & 4.77 & 0.54 & -0.67 & 1.20 \\
Entrepreneurial leadership & 19 & 4.96 & 0.59 & -0.94 & 1.66 \\
Absorptive capability & 12 & 4.53 & 0.57 & -0.43 & 1.05 \\
Slack resources & 10 & 2.81 & 0.53 & -0.36 & 0.83 \\
Technology adoption & 6 & 4.76 & 0.59 & -0.94 & 2.90 \\
Firm performance & 6 & 4.14 & 0.68 & -0.75 & 1.57 \\
\hline
\end{tabular}


Table 2.GOFI Values of the Structural Model Test

\begin{tabular}{lccc}
\hline GOFI & Calculated Values & Standard Value & Conclusion \\
\hline RSMEA & 0.04 & $\leq 0.08$ & Fit is good \\
NFI & 0.97 & $\geq 0.90$ & Fit is good \\
NNFI & 0.99 & $\geq 0.90$ & Fit is good \\
CFI & 0.99 & $\geq 0.90$ & Fit is good \\
IFI & 0.99 & $\geq 0.90$ & Fit is good \\
RFI & 0.96 & $\leq 0.90$ & Fit is good \\
Std. RMR & 0.048 & $\geq 0.90$ & Fit is good \\
GFI & 0.94 & $\geq 0.90$ & Fit is good \\
AGFI & 0.87 & & Fit is marginal \\
\hline
\end{tabular}

Table 3. Validity and Reliability of Measurement CFA Model

\begin{tabular}{|c|c|c|c|c|c|}
\hline $\begin{array}{l}\text { Variables / } \\
\text { Dimensions }\end{array}$ & $* \mathrm{SLF} \geqq 0.5$ & Error & $* \mathbf{C R} \geqq 0.7$ & $* \mathrm{VE} \geqq 0.5$ & Conclusion \\
\hline \multicolumn{2}{|c|}{ Absorptive capability } & & 0.76 & 0.77 & Good reliability \\
\hline AcquL & 0.86 & 0.27 & & & Good validity \\
\hline AssiL & 0.94 & 0.12 & & & Good validity \\
\hline $\operatorname{TranL}$ & 0.90 & 0.20 & & & Good validity \\
\hline ExploL & 0.78 & 0.39 & & & Good validity \\
\hline \multicolumn{2}{|c|}{ Adoption Technology } & & 0.84 & 0.90 & Good reliability \\
\hline ApproL & 1.00 & 0.01 & & & Good validity \\
\hline EffectL & 0.81 & 0.35 & & & Good validity \\
\hline \multicolumn{2}{|c|}{ Entrepreneurial leadership } & & 0.94 & 0.81 & Good reliability \\
\hline BuildL & 0.84 & 0.29 & & & Good validity \\
\hline DefL & 0.85 & 0.28 & & & Good validity \\
\hline Chall & 0.94 & 0.11 & & & Good validity \\
\hline AbsorL & 1.00 & 0.01 & & & Good validity \\
\hline UnderL & 0.92 & 0.15 & & & Good validity \\
\hline \multicolumn{2}{|l|}{ Externalities } & & 0.54 & 0.65 & Less reliable \\
\hline NetL & 0.78 & 0.39 & & & Good validity \\
\hline $\operatorname{Reg} L$ & 0.49 & 0.75 & & & Marginal validity \\
\hline SocL & 0.45 & 0.80 & & & Marginal validity \\
\hline \multicolumn{2}{|c|}{ Firm performance } & & 0.83 & 0.51 & Good reliability \\
\hline FinL & 0.70 & 0.52 & & & Good validity \\
\hline NonfinL & 0.92 & 0.14 & & & Good validity \\
\hline \multicolumn{2}{|c|}{ Resource slack } & & 0.49 & 0.49 & Less reliable \\
\hline TechL & 0.62 & 0.63 & & & Good validity \\
\hline KnowL & 0.96 & 0.10 & & & Good validity \\
\hline HumL & 0.94 & 0.19 & & & Good validity \\
\hline
\end{tabular}


Table 4. Test Results of the Structural Research Model

\begin{tabular}{|c|c|c|c|c|}
\hline Hypotheses & $\begin{array}{l}\text { Latent Variable's } \\
\text { Relationship }\end{array}$ & $\begin{array}{c}\text { Calculated } \\
\text { t-value }\end{array}$ & $\begin{array}{l}\text { Structural } \\
\text { Coefficient }\end{array}$ & Conclusion \\
\hline H1 & $\begin{array}{l}\text { Externalities } \rightarrow \\
\text { Entrepreneurial } \\
\text { leadership }\end{array}$ & 0.23 & 0.04 & $\begin{array}{l}\text { There is an insignificant } \\
\text { positive effect, bypothesis } 1 \text { is } \\
\text { rejected. }\end{array}$ \\
\hline H2 & $\begin{array}{l}\text { Externalities } \rightarrow \\
\text { Absorptive capability }\end{array}$ & 10.61 & 0.85 & $\begin{array}{l}\text { There is a significant positive } \\
\text { effect, bypothesis } 2 \text { is accepted. }\end{array}$ \\
\hline H3 & $\begin{array}{l}\text { Externalities } \rightarrow \text { Slack } \\
\text { resources }\end{array}$ & 0.03 & 0.01 & $\begin{array}{l}\text { There is an insignificant } \\
\text { positive effect, bypothesis } 3 \text { is } \\
\text { rejected. }\end{array}$ \\
\hline H4 & $\begin{array}{l}\text { Absorptive capability } \rightarrow \\
\text { Entrepreneurial } \\
\text { leadership }\end{array}$ & 3.62 & 0.65 & $\begin{array}{l}\text { There is a significant } \\
\text { positive effect, bypothesis } 4 \\
\text { is accepted. }\end{array}$ \\
\hline H5 & $\begin{array}{l}\text { Absorptive capability } \rightarrow \\
\text { Slack resources }\end{array}$ & 2.66 & 0.53 & $\begin{array}{l}\text { There is a significant } \\
\text { positive effect, bypothesis } 5 \text { is } \\
\text { accepted }\end{array}$ \\
\hline H6 & $\begin{array}{l}\text { Absorptive capability } \rightarrow \\
\text { Technology adoption }\end{array}$ & 5.58 & 0.68 & $\begin{array}{l}\text { There is a significant } \\
\text { positive effect, bypothesis } 6 \text { is } \\
\text { accepted }\end{array}$ \\
\hline$H 7$ & $\begin{array}{l}\text { Entrepreneurial leadership } \\
\rightarrow \text { Technology adoption }\end{array}$ & -0.81 & -0.07 & $\begin{array}{l}\text { There is an insignificant } \\
\text { negative effect, hypothesis } 7 \text { is } \\
\text { rejected }\end{array}$ \\
\hline H8 & $\begin{array}{l}\text { Slack resources } \rightarrow \\
\text { Technology adoption }\end{array}$ & -0.62 & -0.05 & $\begin{array}{l}\text { There is an insignificant } \\
\text { negative effect, hypothesis } 8 \text { is } \\
\text { rejected }\end{array}$ \\
\hline H9 & $\begin{array}{l}\text { Technology adoption } \rightarrow \\
\text { Firm performance }\end{array}$ & 5.23 & 0.84 & $\begin{array}{l}\text { There is a significant } \\
\text { positive effect, bypothesis } 9 \text { is } \\
\text { accepted }\end{array}$ \\
\hline
\end{tabular}

The calculated t-values and structural coefficients of each latent variable, and the hypotheses results are presented in Table 4. From the hypotheses testing results, five hypotheses are accepted ( $t$-value $\geq 1.96)$ and four hypotheses are rejected ( $t$-value $<1.96)$. It is surprising, finding that the externalities have no significant effect on both entrepreneurial leadership and slack resources (H1, H3). In conclusion the model demonstrates that the determinant factors of technology's adoption for improving a firm's performance works only through 1 pathway: Externalities -absorptive capability- technology adoption (H2, H6). Even though the absorptive capability has positive significant effects on both entrepreneurial leadership and slack resources (H4, H5), the relationship does not significantly affect the adoption of technology (both $\mathrm{H} 7$ and $\mathrm{H} 8$ are rejected). The study has empirically proven that the effect of dynamic capability -in this study represented by ab- 
sorptive capability- on firms' performance is indirect mediated by technology's adoption (H6, H9).

\section{Discussion}

Starting from the TOE's framework, this study is focusing on the determinant factors of technology's adoption at the firms' level, and especially the role of externalities as the primary antecedent and absorptive capability as a dynamic factor. Through an empirical conceptual model, this study has found and tested the correlation of technology adoption's antecedents -in the form of the TOE's factors- $-(\mathrm{H} 1, \mathrm{H} 3)$, and then connected them to a firm's DCs $(\mathrm{H} 2, \mathrm{H} 4, \mathrm{H} 5)$ and eventually to a firm's performance through technology's adoption (H6, H7, H8, H9). Many studies using the TOE framework have proven that the determinants' factors have a significant relationship with technology's adoption for enhancing firms' performance (Al-Qirim 2006; Jeyaraj et al. 2006; Scupola 2009; Lai 2008; Lin 2013).

However, this study empirically proved that entrepreneurial leadership has an insignificant negative relationship with technology's adoption (H7); as well as slack resources (H8). Based on further investigation most of the process of technology's adoption by PLN's business units is 'bottom-up;' it is likely driven by the organization rather than the management. This is why entrepreneurial leadership has a negative insignificant effect on technology's adoption (Greenberger and Sexton 1988; Roomi and Harrison 2011). The slack resources also have a negative insignificant effect, due to some important resources such as financial and human capital, which are not controllable by the business units' managers (Chau and Hui 2001 and Franquesa and Brandyberry 2009). Those re- sources are mostly managed by PLN's regional offices so that resources are 'given' to the business units (Vanacker et al. 2013).

In addition, previous literature shows that the relationship between TOE's factors theoretically is significantly positive, such as the externalities to entrepreneurial leadership (McGrath and MacMillan 2000; Cohen and Levinthal 1990) and externalities to slack resources (Pfeffer and Salancik 1978; Sharfman et al. 1988; Stevens 2002; Donada and Dostaler 2005). However this study shows that the externalities affect both entrepreneurial leadership and slack resources positively, but not significantly (H1, H3). The insignificant effect of the externalities on entrepreneurial leadership is caused by the relationship between PLN's business units and their networks, such as government agencies, the industry and their professional associations, none of which are relevant to the development of entrepreneurial and leadership capabilities in the organization. A similar reason is also applicable for the positive, insignificant effect of the externalities on the slack resources in PLN's business units (Iacovau et al. 1995, and Lin 2013).

With the recent turbulent and unpredictable circumstances there is a need for directly connecting the TOE's factors to the absorptive capability, especially to show the adoption of technology as a functional competence/capability in a dynamic business environment (H2, H4, H5). Moreover the study empirically proves that the effect of absorptive capability -as a representative of DC on the firm's performance is indirect and - in this research- mediated by technology's adoption (H6, H9). This supports some previous studies (Zott 2003; Helfat and Peteraf 2003; Ambrosini and Bowman 2009; Wang and Ahmed 2007). Practically, the adoption of technology by PLN's business units is mostly 
an output of such absorptive capability, such as knowledge management practices. Technology's adoption is commercial 'knowledge implementation;' it is one of the stages of the knowledge management cycle in an organization. Therefore like other intangible resources; its effect on the organization's performance takes a relatively long time to be felt, as it is not direct.

This study emphasizes that, without absorptive capability -at next higher order- for managing the resource, the core competence (the VRIN resources) of firms will not occur, thus it means no competitive advantages emerge, and the adoption of tech-nology will be less effective (Barney 1991; Priem and Butler 2001). Consequently managers should realize that technology's adoption is not a static process (Moore 1991; Rogers 1995). It is not only about the relationship between resources both inside and outside the organization, but also the ability of the organization to recognize the values of novelty in the external forms, then assimilate and apply them for commercial purposes, or the company's ability to evaluate and utilize external knowledge as the primary purpose of the level of prior/previous knowledge (Link and Siegel 2002; Zaheer and Bell 2005). Considering the externalities as an antecedent, to achieve a successful tech-nology adoption, managers must also acknowledge that the influence of partners such as vendors, associations they belong to, R\&D centers, universities, all commonly known as 'network effects', are likely to significantly impact on technology's adoption since they can affect the expected benefits from new technology that exists with other assets of the firm (AlQirim 2006; Jeyaraj et al. 2006; Scupola 2009).

Examining further the three determinant factors of technology's adoption, this study found the technology adoption organization's typology consists of 8 (eight) levels: 'Ideal' technology adoption with a high absorptive capability (absorp), high entrepreneurial leadership (entrep) and high slack re-

Figure 2. Technology Adoption Organization in a 3D Matrix

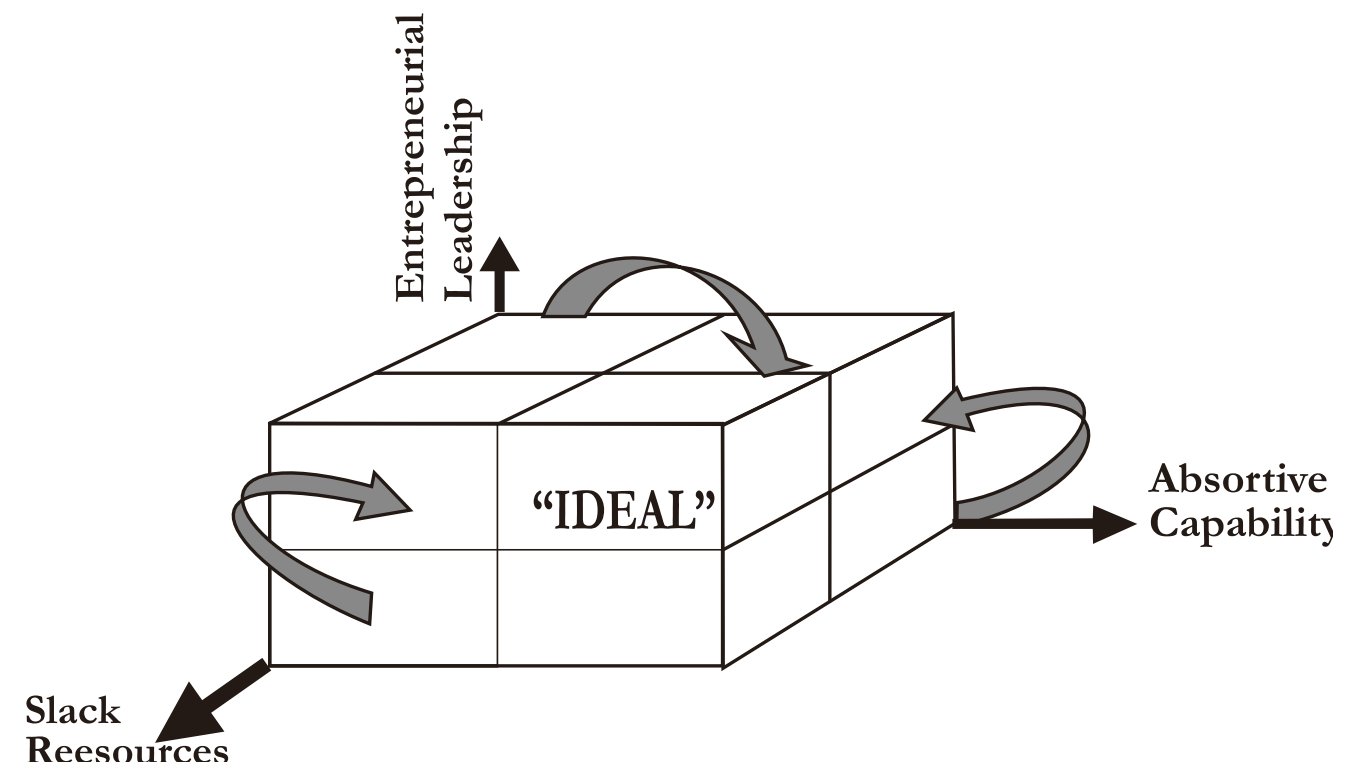


sources (resou), 'pro-active' with high absorp, high entrep and low resou, 'bottom-up' with high absorp, low entrep and high resou, 'organizational' with high absorp, low entrep and low resou, 'top-down' with low absorp, high entrep and high resou, 'entrepreneurial' with low absorp, high entrep and low resou, 'slack' with low absorp, high entrep and low resou and 'stagnant' technology adoption with low absorp, entrep and resou. In summary the technology adoption organization can be plotted as in Figure 2.

This study has examined the organization's typology of technology's adoption related to the firms' performance as in Table 5. It shows that the 'ideal' adoption has the most significant effect on the firm's performance (scoring 4.57 out of 6 ). On the other hand the study found that most of the unit analysis is pro-active organization (202 of 222 units) affecting the firm's performance with a score of 4.21 (lower than the ideal). This finding supports the result of the empirical research, proving that technology's adoption by PLN's business units is significantly proven to enhance the organization's performance.
To achieve a robust hypothetical model, this study has been limited and bounded by several conditions. Firstly, the technology's adoption in this study is defined as 'output;' it is an outcome of the process of search and selection; technology options are selected by the organization; detailed understanding is gained; and the new technology is used in new products/services. This limited the scope of the study, neglected other definitions, and put technology's adoption as just a 'content' of the firm. However many studies argue that technology's adoption is mostly a 'process' in dynamic circumstances. Secondly, this study is conducted at the intra-firm level (business unit) of a utility industry; the findings might not be transferable to other types of organizations. A highly regulated utility, such as the electricity industry, is less influenced by the market, so that an important externality such as pressure from competitors is not applicable. Thirdly, this study relies on 'snap shot' data which do not provide any longitudinal or time series data which examines the past, present, and future of the relationships.

Table 5. The Typology of Technology Adoption Organization

\begin{tabular}{lcccccc}
\hline \multirow{2}{*}{$\begin{array}{c}\text { Technology } \\
\text { Adoption }\end{array}$} & $\begin{array}{c}\text { No. of } \\
\text { Unit }\end{array}$ & Absorp & Entrep & Resou & \multicolumn{2}{c}{ Firm Performance } \\
\cline { 6 - 7 } & 6 & HIGH & HIGH & HIGH & HIGH & Score \\
\hline Ideal & 202 & HIGH & HIGH & LOW & HIGH & 4.21 \\
Pro-active & 0 & HIGH & LOW & HIGH & LOW & - \\
Bottom-up & 10 & HIGH & LOW & LOW & LOW & 3.19 \\
Organizational & 0 & LOW & HIGH & HIGH & LOW & - \\
Top-down & 3 & LOW & HIGH & LOW & LOW & 3.38 \\
Entrepreneurial & 1 & LOW & LOW & HIGH & LOW & 2.31 \\
Slack & 0 & LOW & LOW & LOW & HIGH & - \\
Stagnant & & & & &
\end{tabular}


Therefore further research is highly recommended for 'market-driven' organizations in dynamic industries with tough competition. It is also suggested that further research can be conducted on multi-national organizations and also in countries with different cultures for the external validity of the model. In addition, further surveys can be designed in such a way that firms' performance, technology's adoption and leadership can be measured by longitudinal data, to find their consistency and to investigate further into the process, and not only technology adoption's content.

\section{Conclusion}

The study has investigated the influence of externalities and absorptive capability on the adoption of technology, and others determinant factors for enhancing firms' performance. Four determinant factors which have been examined are: Externalities, slack resources, entrepreneurial leadership and absorptive capability. The successful adoption of technology by a firm can be only achieved by an excellent absorptive capability with the externalities as the antecedent. However the effects of entrepreneurial leadership and slack resources are not significant, even though they are affected significantly by the absorptive capability. The relationship between TOE's components and absorptive capability is positively significant. Meanwhile technology's adoption is proven to mediate the absorptive capability with the performance of a firm.
Practically the model of this study is mostly relevant for top corporate executives (boards of directors) or top management teams, who seek to provide some supporting 'hardware' content such as externalities, resources and leadership, and should improve their firm's 'software' abilities such as the absorptive capability, in order to achieve a successful technology adoption in their organization. Using the eight organizational typologies of technology's adoption they will be able to manage all the determinant factors effectively, and achieve a successful adoption in their organization. Without such a capability -at next higher order- for managing the resource, the core competence (VRIN resources) of a firm will not occur, thus it means no competitive advantages emerge. On the other hand managers should utilize 'vicarious learning' or learning from the actions of other firms (external) because adopting technology is a dynamic processes that can be merged by inter-related organizational responses. Technology's adoption depends on prior knowledge and facilitates the cumulative learning of new related knowledge, efficient and effective coordination or integration of activities internal to the firm, as well as the external coordination of activities and technologies, via formal or informal cooperation between industries, university laboratories, and professional networks. Further research is recommended for different contexts and to focus more on the process rather than the content. 


\section{References}

Abramovitz, M. 1956. Resource and output trends in the United States since 1870. American Economic Revie 46: 5-23.

Abreu, M., V. Grinevich, M. Kitson, and M. Savona. 2008. Absorptive capacity and regional patterns of innovation. Background Paper for the Innovation Nation White Paper. DIUS. London.

Adewoje, J. O., and T. A. Akanbi. 2012. Role of information and communication technology investment on the profitability of small medium scale industries - A case of sachet water companies in Oyo State, Nigeria. Journal of Emerging Trends in Economics and Management Sciences (JETEMS) 3 (1): 64-71.

Al-Qirim, N. 2006. The role of government and e-commerce adoption in small businesses in New Zealand. International Journal of Internet and Enterprise Management 4 (4): 293-313.

Ambrosini, V., and C. Bowman. 2009. What are dynamic capabilities and are they a useful construct in strategic management? International Journal of Management Reviews 11 (1): 29_49.

Amlaku, A., J. Sölkner, R. Puskur, and M. Wurzinger. 2012). The impact of social networks on dairy technology adoption: evidence from Northwest Ethiopia. International Journal of AgriScience 2 (11): 1062-1083.

Argyris, C., and D. Schön. 1978. Organizational Learning: A Theory of Action Perspective. Reading MA: AddisonWesley.

Asress, A., J. Sölkner, R. Puskur, and M. Wurzinger. 2012. The impact of social networks on dairy technology adoption: Evidence from Northwest Ethiopia. International Journal of AgriScience 2 (11): 1062-1083.

Bagozzi, R. P.; Davis, F. D.; Warshaw, P. R. 1992. Development and test of a theory of technological learning and usage. Human Relations 45 (7): 660-686.

Barney, J. B. 1991. Firm resources and sustained competitive advantage. Journal of Management 17 (1): 99120.

Becchetti, L., S. Castriota, and O. Giuntella. 2006. The effects of age and job on the welfare costs of inflation and unemployment: A source of ECB anti-inflation bias? European Journal of Political Economy 26: 137-146.

Benitez-Amado, J. F. J. Llorens-Montes, M. N. Perez-Arostegui. 2010. Information technology-enabled intra-preneurship culture and firm performance. Industrial Management and Data Systems 110 (4): 550-566.

Berndt, E., and C. Morrison. 1995. High-tech capital formation and economic performance in U.S. manufacturing industries: An exploratory analysis. Journal of Econometrics 65 (1).

Bourgeois, L. J. 1981. On the measurement of organizational slack. Academy of Management Review 6 (1): 29-39.

Boyne, G. A., and K. J. Meier. 2009. Environmental turbulence, organizational stability, and public service performance. Administration and Society 40 (8): 799-824.

Bressler, M. S., and L. A. Bressler, and M. E. Bressler. 2011. A study of small business technology adoption and utilization. Academy of Enterpreneurship Journal 17 (2): 49-60.

Brynjolfsson, E., and Hitt. 2000. Beyond computation: Information technology, organizational transformation and business performance. Journal of Economic Perspectives 14 (4). 
Burkart, M., F. Panunzi, and A. Shleifer. 2003. Family firms. The Journal of Finance 58 (5): 2167-2202.

Butler, D. L., and M. Sellbom. 2002. Barriers to adopting technology for teaching and learning. Educause Quarterly 2.

Caloghirou Y, I. Kastelli, and A. Tsakanikas. 2004. Internal capabilities and external knowledge sources: complements or substitutes for innovative performance? Technovation 24 (1): 29-39.

Chakravarthy, B. 1997. A new strategy framework for coping with turbulence. MIT Sloan Management Review (January).

Chanrasekhar, M., and R. M. Sonar. 2008. Impact of information technology on the efficiency and total factor productivity of Indian banks, South Asian Journal Management 15 (3): 74-100.

Christensen, C. M., and M. Overdorf. 2000. Meeting the challenge of disruptive change. Harvard Business Review (March-April).

Cohen, W. M., and D. A. Levinthal, 1990. Absorptive capacity: A new perspective onlLearning and innovation. Administrative Science Quarterly 35 (1): 128-152.

Churchill, R. Q., W. Agbodohu, and P. Arhenful. 2013. An exploratory study of entrepreneurial leadership development of polytechnic students. Journal of Education and Practice 4 (24).

Combe, I. A., and G. E. Greenley. 2004. Capabilities for strategic flexibility: A cognitive content framework. European Journal of Marketing 38 (11/12): 1456-1480.

D’Aveny, R. A. 1994. HyperCompetition, Managing the Dynamics of Strategic Manewvering. Free Press.

Dandago. K. I., and F. B. K. Usman. 2012. Impact of Investment in Information Technology on the return of assets of selected banks in Nigeria. International Journal of Arts and Commerce 1 (5): 235244.

Davis, F. 1989. Perceived usefulness, perceived ease of use, and user acceptance of information technology. MIS Quarterly 13: 319-340.

de Burca, S., B. Fynes, and D. Marshall. 2005. Strategic adoption technology: Extending ERP across the supply chain. Journal of Enterprise Information Management 18 (4): 427-440.

Devarajan, T P., K. Ramachandran and S. Ramnarayan. 2003. Entrepreneurial leadership and thriving innovation activity. Proceedings of $7^{\text {th }}$ International Conference on Global Business and Economic Development.

de Wit, B., and R. Meyer. 2010. Strategy: Process, Content, Context (4 ${ }^{\text {th }}$ ed.). U.K.: Cengage Learning EMEA.

Diego Comin, D. A., and M. Mestieri. 2010. The intensive margin of technology adoption. Harvard Business School BGIE Unit Working Paper No. 11-026. Available at SSRN: https://ssrn.com/abstract=1676302 or http://dx.doi.org/10.2139/ssrn.1676302.

Domegan, C. T. 1996. The adoption of information technology in customer service. European Journal of Marketing 30 (6).

Dussauge, P. 1992. Strategic Technology Management. New York: J. Wiley \& Sons.

Eisenhardt, K. M., and J. A. Martin. 2000. Dynamic capabilities: What are they? Strategic Management Journal 21: 1105-1121.

Felin T., and N. Foss. 2005. Strategic organization: A field in search of micro-foundations. Strategic Organization 3: 441-455

Gladys, L-A. 2002. Technology and Firm Performance in Mexico. Washington: World Bank.

Grant, R. M. 2003. Strategic planning in a turbulent environment: Evidence from the oil majors. Strategic Management Journal 24 (6): 491-517. 
Gupta, V., I. C. MacMillan, and G. Suriec. 2004, Entrepreneurial leadership: Developing and measuring a cross-cultural construct. Journal of Business Venturing 19 (2): 241-260.

Hall, B. H., and B. Khan. 2002. Adoption of new technology. In New Economy Handbook (Hall and Khan)..

Hejazi, S. A. M., M. M. Malei, and M. J. Naeiji. 2012. Designing a scale for measuring entrepreneurial leadership in SMEs. In International Conference on Economics, Marketing and Management, IPEDR 28: 71 77.

Helfat, C. E., and M. A. Peteraf . 2003. The dynamic resource-based view: Capability lifecycles. Strategic Management Journal 24 (10): 997 - 1010.

Hikmet, N., A. Bhattacherjee, N. Menachemi, V. O. Kayhan, and R. G. Brooks. 2008. The role of organization factors in the adoption of healthcare information technology in Florida hospitals. Healthcare Management Science (11) (1): 1-9.

Hitt M. A., R. D. Ireland, D. G. Sirmon, and C. A. Trahms. 2011. Strategic entrepreneurship: Creating value for individuals, organizations, and society. Academy of Management Perspectives 25 (2): 57-76.

Hitt, M. A., R. D. Ireland, and R. Hoskisson. 2006. Strategic Management; Competitiveness and GlobalizationConcepts ( $2^{\text {nd }}$ ed.). Canada: Thomson Nelson (Canadian Edition).

Ireland, R. D., M. A. Hitt, and D. G. Sirmon. 2003. Strategic entrepreneurship: The construct and its dimensions. Journal of Management 29 (6): 963-989.

Jawabreh, O. A., M. Allahham, A. Alrjoub, and M. Ahmad.. 2012. Impact of information technology on the profitability of the airline industry: A case study of royal Jordanian Airlines. International Journal of Business and Management 7 (18): 149-157.

Jeyaraj, A., R. Rottman, and M. Lacity. 2006. A review of the predictors, linkages, and biases in IT innovation adoption research. Journal of Information Technology 21 (1): 1-23.

Johnsen, R. E. and D. Ford, 2006), Interaction capability development of smaller suppliers in relationships with larger customers. Industrial Marketing Management 35: 1002-1015.

Johnson, G., K. Scholes, and R. Whittington. 2008. Exploring Corporate Strategy: Text and Cases (8th ed.). Prentice Hall.

Kabiru I. D., and F. B. K. Usman. 2012. Impact of investment in information technology on the return of assest of selected banks in Nigeria. International Journal of Arts and Commerce 1 (5).

Kiiski, S., and M. Pohjola. 2002. Cross-country diffusion of the internet. Information Economics and Policy 14 (2) (June): 297-310.

Kotler, P., and K. L. Keller. 2006. Marketing Management $\left(12^{\text {th }}\right)$. Prentice Hall.

Lane, P. J. and M. Lubatkin, 1998, Relative absorptive capacity and interorganizational learning. Strategic Management Journal 19 (5) (May): 461-477.

Landry, R., N. Amara, and M. Lamari. 2002. Does social capital determine innovation? To what extent? Tecbnological Forecasting and Social Change 69 (7): 681-701.

Lai, V. S. 2008. The information system strategic of MNC affiliates: A technology-organization-environment analysis. Journal of Global Information Management 16 (3): 74-96.

Lee, J. H., and S. Venkataraman. 2006. Aspirations, market offerings, and the pursuit of entrepreneurial opportunities. Journal of Business Venturing 21 (1): 107-123.

Lee, O-K, M. Wang, Lim, K. H., Lim, and Z. Peng. 2009. Knowledge management system diffusion in Chinese enterprises: A multistage approach using the technology-organization-environment framework. Journal of Global Information System 17 (1): 70-84. 
Lewin, A. Y., and S. Massini. 2003. Knowledge Creation and Organisational Capabilities of Innovating and Imitating Firms. Basingstoke Publication.

Lin, H. F., and S. M. Lin. 2008. Determinants of e-business diffusion: A test of the technology diffusion perspective. Technovation 28: 135-145.

Lin, H-F. 2013. Understanding the determinants of electronic supply chain management system adoption: Using the technology-organization-environment framework. Technological Forecasting and Social Change. Information Systems Spending, Management Science 42 (4) (April): 541-558.

Madlener, R., and C. Schmid. 2003. Adoption and diffusion of decentralized energy conversion technologies: The success of engine cogeneration in Germany. Energy and Environment 14 (5).

Malhotra, A., S. Gosain, and O. A. El-Sawy. 2006. Absorptive capacity configurations in supply chains: Gearing for partner-enabled market knowledge creation. MIS Quarterly 29 (1): 145-187

Majumdar, S. K., O. Carare, and H. Chang. 2010. Broadband adoption and firm productivity: Evaluating the benefits of general purpose technology. Industry and Corporate Change 19 (3): 641-674.

Majundar, S. K. and S. Venkataraman. 1998. Network effect and the adoption of new technology: Evidence from the US telecommunication industry. Strategic Management Journal 19: 1045- 062.

Makadok, R. 2001. Toward a synthesis of the resource-based and dynamic-capability views of rent creation. Strategic Management Journal 22 (5): 387-401.

McCardle, K. F. 1985. Information acquisition and the adoption of new technology. Management Science (31).

McGrath, R. G., and I. C. MacMillan. 2000. The Entrepreneurial Mindset: Strategies for Continuously Creating Opportunity in an Age of Uncertainty. Boston, Mass.: Harvard Business School Press.

McKelvie, A., and P. Davidsson. 2009. From resource base to dynamic capabilities: An investigation of new firms. British Journal of Management 20 (s1): S63-S80.

Mirvis, P. H., A. L. Sales, and E. J. Hackett. 1991. The implementation and adoption of new technology in organizations: Work, people, and culture. Human Resources Management 30 (1) (Spring): 113-139.

Moore, . C., and I. Benbazat. 2001. Development of instrument to measure the perceptions of adopting an information technology innovation. Information System Research 2 (3): 192-222.

Moore, G. C., and I. Benbasat. 1996. Integrating diffusion of innovations and theory of reasoned action models to predict utilization of information technology by end-users. Diffusion and Adoption of Information Technology. Springer US: 132-146.

Morris, M.H. (1998), "Entrepreneurial Intensity; Sustainable Advantages for Individuals, Organizations and Societies", Westport, CT: Quorum.

Nonaka, I., and G. von Krogh. 2009. Tacit knowledge and knowledge conversion: Controversy and advancement in organizational knowledge creation theory. Organization Science 20 (3): 635-652.

Oliveira, T., and M. F. Martins. 2011. Literature review of information technology adoption models at firm level. The Electronic Journal Information Systems Evaluation 14 (1): 110-121.

Pan, M-J., and W-Y. Jang. 2008. Determinants of the adoption of enterprise resource planning within the technology-organization-environment framework: Taiwan's communication industry. The Journal of Computer Information Systems 48 (3): 94-102.

Parente, S. L., and E. C. Prescott. 1994. Barriers to technology adoption and development. The Journal of Political Economy 102 (2): 298-321. 
Pettus, M. L., Y. Y. Kor, and J. T. Mahoney. 2009. A theory of change in turbulent environments: The sequencing of dynamic capabilities following industry regulation. International Journal Strategic Change Management (1) (3).

Plouffe, C. R., J. S. Hulland, and M. Vandenbosch. 2001. Research report: Richness versus parsimony in modeling technology adoption decisions-understanding merchant adoption of a smart cardbased payment system. Information Systems Research 12 (2): 208-222.

Porter, M. 1985. Competitive Advantage: Creating and Sustaining Superior Performance. Harvard University Press..

Porter, M., and V. Millar. 1985. How information gives you competitive advantage. Harvard Business Review 63 (4): 149-160.

Priem, R. L., and J. E. Butler. 2001. Is the resource based view a useful perspective of strategic management research? Academy of Management. The Academy of Management Review 26 (1). ABI/INFORM Global

Quinn, J. B., and M. N. Baily. 1994. Information technology: Increasing productivity in services. Academy of Management Executive 8 (3): 28-51.

Raymond, L., and S. Blili. 1997. Adopting EDI in a network organization: The case of subcontracting SMEs. European Journal of Purchasing and Supply Management 3 (3): 165-175.

Rayport, J. F., and B. J. Jaworski. 2004. Best Face Forward, Why Companies Must Improve Their Service Interfaces with Customers. Harvard Business School Press.

Raza, I., Chaudhry, A. R., and Rehman, Z-R.. 2010. Forced adoption of technology due to energy crisis. Interdisciplinary Journal of Contemporary Research Business 2 (1): 313-326.

Repenning, N. P., and J. D. Sterman. 2002. Capability traps and self-confirming attribution errors in the dynamics of process improvement. Administrative Science Quarterly 47 (2): 265-295.

Rindova, V. P., and S. Kotha. 2001. Continuous "morphing": Competing through dynamic capabilities, form, and function. Academy of Management Journal 44 (6): 1263-1280.

Rogers, E. M. 1962. Diffusion of Innovations. Glencoe: Free Press.

Rogers, E. M. 1983. Diffusion of Innovations. New York: Free Press.

Rogers, E. M. 1995. Diffusion of Innovations (4th ed.). New York: The Free Press.

Sabbaghi, A., and G. Vaidyanathan. 2008. Effectiveness and efficiency of RFID technology in supply chain management: Strategic values and challenges. Journal of Theoretical and Applied Electronic Commerce Research 3 (2): 71-81.

Saloner, G., and S. Shepard. 1995. Adoption of technologies with network effects: An empirical examination of the adoption of automated teller machines. RAND Journal of Economics 26: 479-501.

Sarker, S., and J. S. Valacich. 2010. An alternative to methodological individualism: A non reductionist approach to studying technology adoption by groups. MIS Quarterly 34 (4): 779-808.

Schumpeter, J. A. 1943. Capitalism, Socialism and Democracy. Unwin Paperback.

Scupola, A. 2009. SMEs' e-commerce adoption: Perspectives from Denmark and Australia. Journal of Enterprise Information Management 22 (1/2): 152-166.

Shu, W. and P. A. Strassmann. 2005. Does information technology provide banks with profit? Information and Management 42 (5): 781-787.

Silva, L. 2007. Post -positivist review of the technology acceptance model. Journal of the Association for Information Systems 8 (4): 255-266. 
Sinha, R. K., and C. H. Noble. 2008. The Adoption of Radical Manufacturing Technologies and Firm Survival. Strategic Management. Journal 29: 943-962.

Solow, R. M. 1957. A contribution to the theory of economic growth. Quarterly Journal of Economics (February).

Srinivasan, R., G. L. Lilien, and A. Rangaswamy. 2002. Technological opportunism and radical technology adoption: An application to e-business. Journal of Marketing 66 (3): 47.

Taylor, S., and P. Todd. 1995. Understanding information technology usage: A test of competing models. Information Systems Research 6 (2): 144-174.

Teece, D. J.; G. Pisano, and A. Shuen. 1997. Dynamic Capabilities and Strategic Management. Strategic Management Journal, 18 (7): 509-533.

Teece, D. J. 2007. Explicating dynamic capabilities: The nature and micro-foundations of (sustainable) enterprise performance. Strategic Management Journal 28 (13): 1319-1350.

Tornatzky, L., and M. Fleischer. 1990. The Process of Technology Innovation. Lexington, M.A: Lexington Books.

van Ark, B., M. O’Mahony, and M. P. Timmer. 2008. The productivity gap between Europe and the United States: Trends and causes. Journal of Economic Perspectives 22 (1): 25- 44.

Van De Ven, A. H., and M. S. Poole. 1999. Explaining development and change in organizations. Academy of Management Review 20 (3): 510-540.

Venkatesh, V., M. G. Morris, G. B. Davis, and F. D. Davis. 2003. User acceptance of information technology: Toward a unified view. MIS Quarterly 27 (3): 425-478.

Venkatesh, V., M. G. Morris, G. B. Davis, and F. D. Davis. 2003. User acceptance of information technology: Toward a unified view. MIS Quarterly 27 (3): 425-478.

Wang, C. L., and P. K. Ahmed. 2007. Dynamic capabilities: A review and research Agenda. The International Journal of Management Reviews 9 (1): 31-51.

Wang, H., J. Choi, G. Wan, and J. Q. Dong. 2013. Slack resources and the rent-generating potential of firm-specific knowledge. Journal of Management: 0149206313484519.

Watengere, K. 2010. Realizing farmer's objectives - vital to adoption process of fish farming technology: The case of selected villages in Eastern Tanzania. Advance Journal of Food, Science and Technology 2 (2).

Wijanto, S. H. 2008. Structural Equation Modeling with LISREL 880. Jakarta, Indonesia: Graha Ilmu Jakarta.

Zaheer, A., and G. G. Bell. 2005. Benefiting from network position: firm capabilities, structural holes, and performance. Strategic Management Journal 26 (9): 809-825.

Zahra, S. A., and G. George. 2002. Absorptive capacity: A review, re-conceptualization, and extension. Academy of Management Review 27: 185 - 203.

Zahra, S. A., H. J. Sapienza, and P. Davidsson. 2006. Entrepreneurship and dynamic capabilities: a review, model and research agenda. Journal of Management Studies 43 (4): 917-955.

Zhu, K., and J. P. Weyant. 2003. Strategic decision of new technology: Adoption under asymmetric information: A game theoretic model. Decision Science 34 (4).

Zollo, M. and S. G. Winter. 2002. Deliberate learning and the evolution of dynamic capabilities. Organization Science 13 (3): 339 - 351.

Zott, C. 2003. Dynamic capabilities and the emergence of intra-industry differential firm (sustainable) enterprise performance. Strategic Management Journal 28 (13). 


\section{Appendix 1. Factor Analysis Results}

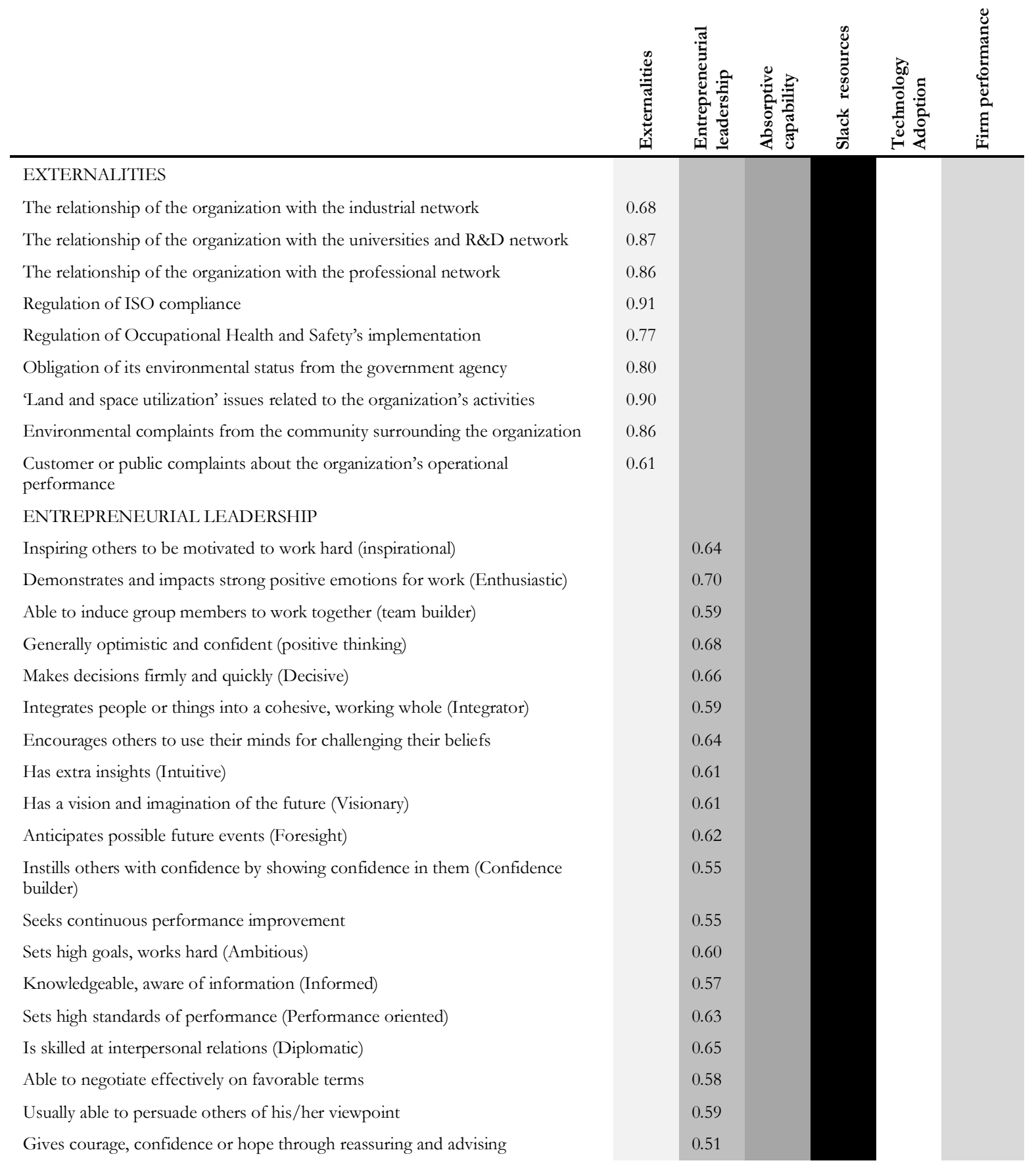




\section{Continued Appendix 1}

\begin{tabular}{|c|c|c|c|c|c|c|}
\hline & 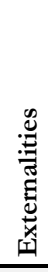 & 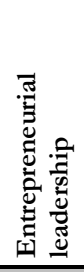 & 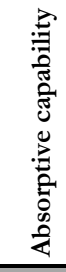 & 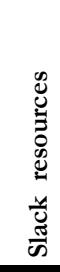 & 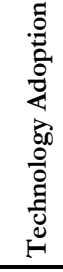 & 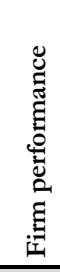 \\
\hline \multicolumn{7}{|l|}{ ABSORPTIVE CAPABILITY } \\
\hline The capacity to learn about all the employees within the organization & & & 0.88 & & & \\
\hline $\begin{array}{l}\text { The articulated goal and milestones mindset of all the employees within the } \\
\text { organization }\end{array}$ & & & 0.90 & & & \\
\hline $\begin{array}{l}\text { The active involvement of all employees in many activities within the } \\
\text { organization }\end{array}$ & & & 0.88 & & & \\
\hline Knowledge embeddedness within the organization & & & 0.62 & & & \\
\hline Methodology used for capturing knowledge in the organization & & & 0.78 & & & \\
\hline Management of championship practices in the organization & & & 0.75 & & & \\
\hline Knowledge socialization activities in the organization & & & 0.79 & & & \\
\hline Knowledge externalization practices in the organization & & & 0.78 & & & \\
\hline Knowledge combination practice in the organization & & & 0.84 & & & \\
\hline New knowledge's application and link to working practices & & & 0.77 & & & \\
\hline New knowledge's application to improve problem solving capabilities & & & 0.99 & & & \\
\hline New knowledge's application to improve team synergy & & & 0.88 & & & \\
\hline \multicolumn{7}{|l|}{ SLACK RESOURCES } \\
\hline The complexity of the technology which will be adopted & & & & 0.58 & & \\
\hline The availability of the technology which will be adopted & & & & 0.64 & & \\
\hline The maturity level of the technology which will be adopted & & & & 0.75 & & \\
\hline $\begin{array}{l}\text { The compatibility of the technology which will be adopted with that existing in } \\
\text { the firm }\end{array}$ & & & & 0.76 & & \\
\hline Community Of Practices (COP) status in the organization & & & & 0.51 & & \\
\hline Knowledge Management (KM) status in the organization & & & & 0.92 & & \\
\hline Knowledge sharing activities in the organization & & & & 0.85 & & \\
\hline Availabilities of the skilled employees in the organization & & & & 0.57 & & \\
\hline Level of under-utilized employees in the organization & & & & 0.62 & & \\
\hline Educational and training in the organization & & & & 0.91 & & \\
\hline TECHNOLOGY ADOPTION & & & & & & \\
\hline The technology fits with the organization's operational activities & & & & & 0.55 & \\
\hline The technology used is financially feasible & & & & & 0.62 & \\
\hline The technology used is technically feasible & & & & & 0.64 & \\
\hline The technology used makes problem solving faster in the organization & & & & & 0.62 & \\
\hline The technology used helps to solve the organization's problems in a better way & & & & & 0.65 & \\
\hline $\begin{array}{l}\text { The technology used provides more access and information needed by the } \\
\text { organization }\end{array}$ & & & & & 0.51 & \\
\hline
\end{tabular}


GadjahMada International Journal of Business-September-December, Vol. 18, No. 3, 2016

\section{Continued Appendix 1}

\begin{tabular}{|c|c|c|c|c|c|c|}
\hline & 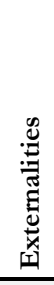 & 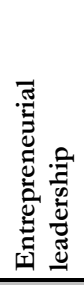 & 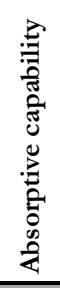 & 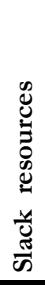 & 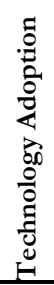 & 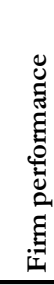 \\
\hline \multicolumn{7}{|l|}{ FIRM PERFORMANCE } \\
\hline The costs of production of the organization & & & & & & 0.98 \\
\hline The financial / non technical losses of the organization & & & & & & 0.98 \\
\hline The organization's productivity & & & & & & 0.55 \\
\hline The services and products' quality delivered by the organization & & & & & & 0.91 \\
\hline The organization's image & & & & & & 0.88 \\
\hline The customers' relationship with the organization & & & & & & 0.59 \\
\hline
\end{tabular}

